\title{
Appropriate Use of Proton Pump Inhibitor in Inpatients of Cen- tral Army Gatot Soebroto Hospital
}

\author{
Meutia Anindita ${ }^{1}$, Nadia Farhanah Syafhan ${ }^{1}$, Yetti Hersunaryati ${ }^{2}$, Retnosari Andrajati ${ }^{1}$ \\ 'Clinical Pharmacy Department, Faculty of Pharmacy, Universitas Indonesia, INDONESIA. \\ ${ }^{2}$ Gatot Soebroto Army Center Hospital, INDONESIA.
}

\begin{abstract}
Background: Evaluation of the use of Proton Pump Inhibitors (PPIs) perceiving the high use of PPIs and likely impacts from inappropriate use of PPPs. The aim of this study was to evaluate the use of PPI on in-patients at Gatot Soebroto Army Center Hospital. Material and Methods: the study design was observational analytic descriptive with prospective data collection method base on prescription and medical record. The sample was data of entire adult in-patients with Indonesian National Health Insurance who used PPI at Internal Diseases Department. PPI use was evaluated based on rationality and therapy effectiveness. Results: Analysis carried out on 153 PPIs therapy of 91 in-patients. The percentages of PPIs therapies with appropriate indication was $77.78 \%$, appropriate drug selection was $77.78 \%$, appropriate patient condition was $98.69 \%$, appropriate dose was 4.58\%, appropriate therapy duration was $66.01 \%$ and therapy effectiveness was $86.27 \%$. Only $3.92 \%$ PPIs therapies were rational regarding all the appropriate criteria fulfillness. Conclusion: Monitoring and
\end{abstract}

evaluation of PPIs use should be done for attaining properly outcome.

Key words: Proton Pump Inhibitor, Appropriateness, In-patien, Indonesian National Health Insurance.

Correspondence :

Retnosari Andrajati

Clinical Pharmacy Department, Faculty of Pharmacy, Universitas Indonesia, INDONESIA.

Phone no: 62217270031

Email: andrajati@farmasi.ui.ac.id

DOI: $10.5530 /$ jyp.2017.1s.3

\section{INTRODUCTION}

Proton pump inhibitors (PPIs) have been among the most widely sold drugs worldwide because of their outstanding efficacy and safety. ${ }^{1}$ In 2008, PPIs ranked the third highest-selling drug in the United States. ${ }^{2}$ Esomeprazole and pantoprazole were ranked the third and fifth most prescribed drugs in Australia in 2012-2013. ${ }^{3}$ Certain clinical studies stated that PPIs are safe and well tolerated if taken correctly. ${ }^{4}$

Recent studies showed some concerns about long-term PPI consumption, including PPI-clopidogrel drug interaction; the possibility of PPIs reducing calcium absorption and vitamin B12, magnesium, and iron levels; long-term acid suppression leading to the development of atropic,gastritis which could be a cancer precursor; PPI being associated with infection risks (pneumonia, Clostridium difficile); and PPIs increasing the risk of bone fractures. ${ }^{2}$ Because of the negative effect of incorrect usage and overdose of PPIs, it is very important for physicians to only prescribe these drugs when needed. ${ }^{4}$ One study in Indonesia showed that there were $55.33 \%$ correct diagnoses and treatment effectiveness was $92.38 \% .^{5}$

According to Cipolle, Strand, and Morley (1998), the pharmacist has a responsibility in achieving effective treatment. On the basis of pharmaceutical care concepts, pharmacists have responsibilities in identifying, solving, and preventing problems regarding drugs; ensuring the patients get appropriate treatment that is effective and safe and can reach the expected results; and ensuring the purpose of the treatment and optimum outcome is achieved. ${ }^{6}$

Gatot Soebroto Army Center Hospital (GSACH) is a public hospital with 687 beds which is gastrointestinal disorder with the possibility of a high rate of PPI consumption. The purpose of this study was to evaluate the appropriateness and effectiveness of PPI therapy at the GSACH.

\section{METHOD}

This was a descriptive observational study with prospective data collection. Data were prescriptions and medical records of adult inpatients at the Internal Disease Ward of GSACH Only patients who were covered by National Health Insurance from February to April 2016 were assessed. The appropriateness of indication, drug selection, dose, and duration of therapy was assessed according to the literature. ${ }^{7,8,9,10}$ The effectiveness of the therapy was assessed according to the patients' complaints.

\section{RESULTS AND DISCUSSION}

We collected 153 PPI usage data of 91 patients. The prevalence of PPI usage in patients was higher among women at $58.24 \%$. The highest PPI consumption was found in the 46-65-year-old age group at $39.56 \%$, while the average age was 48.1 years old. These results were similar to those of the Center for Drug Evaluation and Research at the U.S. Food and Drug Administration (FDA) published in 2010, which showed that PPI was consumed by $57.7 \%{ }^{9}$ women, while the Muya study showed that $64.3 \%$ women consumed PPI. ${ }^{10}$ The characteristic of patients which were use PPIs were shown at Table 1.

Only two PPIs were prescribed, namely omeprazole and lansoprazole; the majority used omeprazole (99.35\%), which was mostly administered parenterally $(67.97 \%)$. These results were similar to a study at a hospital in Australia, where omeprazole was prescribed $40.2 \%$ of the time, while lansoprazole was only $7 \% .{ }^{11}$ Other types of PPIs (rabeprazole, pantoprazole, and esomeprazole) did not show up, because only omeprazole and lansoprazole were listed under National Formulary. PPI treatment was given mostly as intravenous preparations, because patients in this study were treated as inpatients; hence, it was more appropriate to be given intravenously. The description of PPI treatment was shown at Table 2. 
Table 1: Characteristic of patients

\begin{tabular}{|c|c|c|}
\hline Characteristic & $\begin{array}{c}\text { Total } \\
(\mathrm{N}=91)\end{array}$ & Percentage (\%) \\
\hline \multicolumn{3}{|l|}{ Gender } \\
\hline Woman & 53 & 58,24 \\
\hline Man & 38 & 41,76 \\
\hline \multicolumn{3}{|l|}{ Age } \\
\hline $17-25$ years old & 10 & 10,99 \\
\hline $26-45$ years old & 28 & 30,77 \\
\hline 46-65 years old & 36 & 39,56 \\
\hline$>65$ years old & 17 & 18,68 \\
\hline average: 48,1 years old & & \\
\hline \multicolumn{3}{|l|}{ Main Diagnosis } \\
\hline DHF (dengue hemorrhagic fever) & 19 & 20,88 \\
\hline Dyspepsia & 10 & 10,99 \\
\hline GEA (acute gastroenteritis) & 8 & 8,79 \\
\hline DM (diabetes mellitus) & 6 & 6,59 \\
\hline Anemia & 5 & 5,49 \\
\hline Tumor \& cancer & 5 & 5,49 \\
\hline Stroke & 4 & 4,40 \\
\hline Gastritis & 4 & 4,40 \\
\hline $\begin{array}{l}\text { GERD (gastroesophageal reflux } \\
\text { disease }\end{array}$ & 4 & 4,40 \\
\hline Ascites & 3 & 3,30 \\
\hline Sepsis & 3 & 3,30 \\
\hline CKD (chronic kidney disease) & 3 & 3,30 \\
\hline Elektrolit imbalance \& dehydration & 3 & 3,30 \\
\hline Melena \& hematemesis & 2 & 2,20 \\
\hline Thrombocytopenia & 2 & 2,20 \\
\hline Appendicitis & 2 & 2,20 \\
\hline Cephalgia & 1 & 1,10 \\
\hline Angioedema & 1 & 1,10 \\
\hline AIDS & 1 & 1,10 \\
\hline Hypoglychaemia & 1 & 1,10 \\
\hline Cirrhosis & 1 & 1,10 \\
\hline Typhoid fever & 1 & 1,10 \\
\hline Colic abdomen & 1 & 1,10 \\
\hline Hepatomegaly & 1 & 1,10 \\
\hline
\end{tabular}

The highest prevalence of PPI usage was $68.63 \%$ for the dose of $40 \mathrm{mg}$ / day for omeprazole. The highest percentage for PPI duration of administration was $39.22 \%$ for 1 x $40 \mathrm{mg}$ omeprazole for more than 2 weeks of administration. In this study, 1 x $40 \mathrm{mg}, 2$ x $40 \mathrm{mg}$, and 2 x $20 \mathrm{mg}$ omeprazole, as well as $2 \times 30 \mathrm{mg}$ lansoprazole, treatment was given for less than 2 weeks may be caused by the patient's complaint had been diminished or disappeared. Omeprazole 1 x $20 \mathrm{mg}$ and 1 x $40 \mathrm{mg}$ treatment given for 2-4 weeks was approved for dyspepsia treatment, according to DIH and IONI. ${ }^{12,13}$

A study in Canada was comparing the effectivity of lansoprazole and omeprazole in inhibiting acid secretion. This study concluded that lan-

\section{Table 2: Description of PPIs treatment}

\begin{tabular}{ccr}
\hline PPI treatment & Total $(\mathbf{N}=153)$ & Percentag \\
\hline Types of PPI & & \\
Omeprazole & 152 & 99,35 \\
Lansoprazole & 1 & 0,65 \\
Dosage & & \\
Omeprazole & & 4,58 \\
$20 \mathrm{mg} /$ day & 7 & 68,63 \\
$40 \mathrm{mg} /$ day & 105 & 0,65 \\
$60 \mathrm{mg} /$ day & 1 & 25,49 \\
$80 \mathrm{mg} /$ day & 39 & 0,65 \\
Lansoprazole & &
\end{tabular}

\section{Dose Regimen}

Omeprazole

$\begin{array}{ccc}1 \times 20 \mathrm{mg} & 7 & 4,58 \\ 2 \times 20 \mathrm{mg} & 40 & 26,14 \\ 3 \times 20 \mathrm{mg} & 1 & 0,65 \\ 1 \times 40 \mathrm{mg} & 65 & 42,68 \\ 2 \times 40 \mathrm{mg} & 39 & 25,49 \\ \text { Lansoprazole } & & \\ 2 \times 30 \mathrm{mg} & 1 & 0,65\end{array}$

Route of Administration

Omeprazole

Intravena

Peroral

67,79

Lansoprazole

$60 \mathrm{mg} /$ day

31,37

0,65

\section{Duration of Adminsitration}

Omeprazole

1 x $20 \mathrm{mg}<2$ weeks

4,58

$1 \times 20 \mathrm{mg} 2-4$ weeks

0,00

$1 \times 20 \mathrm{mg}>4$ weeks

0,00

$2 \times 20 \mathrm{mg}<2$ weeks

14,84

$2 \times 20 \mathrm{mg} 2-4$ weeks

1,31

$2 \times 20 \mathrm{mg}>4$ weeks

0,00

$3 \times 20 \mathrm{mg}<2$ weeks

0,65

$3 \times 20 \mathrm{mg} 2-4$ weeks

0,00

$3 \times 20 \mathrm{mg}>4$ weeks

0,00

$1 \mathrm{x} 40 \mathrm{mg}<2$ weeks

39,22

1 x 40 mg 2-4 weeks

4,58

$1 \times 40>4$ weeks

$2 \times 40 \mathrm{mg}<2$ weeks

0,00

$2 \times 40 \mathrm{mg}$ 2-4 weeks

23,53

$2 \times 40 \mathrm{mg}>4$ weeks

0,65

0,00

Lansoprazole

$2 \times 30 \mathrm{mg}<2$ weeks

2 x $30 \mathrm{mg}$ 2-4 weeks

$2 \times 30 \mathrm{mg}>4$ weeks 
soprazole $30 \mathrm{mg}$ was more effective in increasing $\mathrm{pH}$ intra-gastric until more than $40 \mathrm{mg}$, compared with omeprazole $20 \mathrm{mg} .{ }^{14}$ Another study that tested the antisecretion of gastric acid activity showed that lansoprazole did not exhibit any significant difference with omeprazole in potential and action duration terms. ${ }^{15}$ Omeprazole was more prescribed than lansoprazole in this study, possibly because the former was cheaper. ${ }^{16}$

The prevalence of PPI usage with the appropriate indication was found in $77.78 \%$. There were 25 cases with main diagnoses suitable for PPI indications, which were recommended by DIH and IONI, including 6 cases of GERD and 19 cases of dyspepsia. A previous study reported that most patients (38.1\%) suffering from dyspepsia were patients in the 46-65 age group..$^{10}$ Krause (2002) stated that age was associated with dyspepsia, and that in advanced ages, $50 \%$ of dyspepsia incidence was caused by $\mathrm{H}$. pylori infections and the remaining $50 \%$ was caused by the patient's lifestyle and food consumption. ${ }^{17}$

In this study, PPI consumption for DHF as the main diagnosis was $20.88 \%$. This result was dissimilar to another study, in which GERD was found in first place with $73.2 \%$ and dyspepsia in sixth place with $2.1 \%{ }^{18}$ The prevalence of DHF in this study was affected by high DHF cases during the study period. The clinical manifestations of DHF in the febrile period were nausea, vomiting, and stomachache. ${ }^{19}$

There were 34 cases with inappropriate diagnoses and without complaints that needed PPI treatment based on the information provided from medical records. In another study, 54\% of patients were prescribed PPI for reasons other than the indications. According to the researchers, the misindication of PPIs could be caused by the recent guidelines and expert opinions about dyspepsia management and PPI usage, which was too stiff/restricting and not consistent with the patient's wishes and physician's experiences. ${ }^{20}$ The use of PPI from the indications may cause denial of the actual indications and relevant duration of administration; hence, it is necessary to communicate appropriate PPI indications to the hospital team. ${ }^{21}$ In this study, no patients were pregnant or breastfeeding; these women cannot consume omeprazole, which is a high-risk medicine for pregnant mothers and can be contained in breastmilk. ${ }^{12}$

The prevalence of PPI use with the appropriate patient assessment was found in $98.69 \%$. However, $1.31 \%$ of PPI use was inappropriate with the patient's condition. There were two cases where the patients experienced hepatic cirrhosis, but PPIs in this case did not need to be changed or removed from treatment but only adjusted for appropriate dosage..$^{22,23}$

The appropriate dose of PPI was found in $4.58 \%$. In 106 cases with dyspepsia indication, PPI was prescribed in higher doses than the usual PPI dose for dyspepsia, which was $20 \mathrm{mg} /$ day. ${ }^{12,13}$ There were four cases of GERD indication, for which higher than the usual PPI dose ( $40 \mathrm{mg} /$ day) was prescribed. ${ }^{12,13}$ The overdose of PPI can lead to hypergastrinemia, since PPI works as a strong inhibitor of acid secretion. Patients who take PPI also have a risk of gastroenteritis caused by pathogenic microorganisms. ${ }^{4}$ The higher dose of PPI can be prescribed for the following indications: maintenance dose for severe GERD; chronic cough related to GERD; empirical diagnosis and treatment for laryngopharyngeal reflux; PPI diagnostic test for uncomplicated GERD and non-cardiac chest pain; and the prevention of peptic ulcer rebleeding. ${ }^{24}$

In 34 cases, PPI was prescribed in an inappropriate dose related to unsuitable indications. According to DIH (Drug Information Handbook) and IONI, omeprazole in $40 \mathrm{mg}$ /day dosage form can be given to treat gastric ulcer, duodenal ulcer, and peptic ulcer, while the usual dose of omeprazole to treat dyspepsia according to IONI is $20 \mathrm{mg} /$ day. ${ }^{12,13}$

The prevalence of PPI usage in the appropriate duration of administration was found in $66.01 \%$. The duration of PPI administration consumption for dyspepsia as recommended by DIH and IONI is 2-4 weeks. ${ }^{12,13}$ There were two cases of dyspepsia with PPI prescriptions that met the standard range. There were 93 cases of dyspepsia in which PPI was prescribed for less than 2 weeks. The duration of PPI administration for GERD as recommended by DIH and IONI is $4-8$ weeks. ${ }^{12,13}$ In all cases of GERD indication, PPI was prescribed for less than 4 weeks. In 34 cases, PPI was prescribed for an inappropriate duration because it was not suitable for the indications.

The effectiveness of PPI therapy was found in 135 cases (88.24\%) based on decreasing complaints of nausea, vomiting, bloating, stomach ache, and heartburn. There were five cases of nausea after consuming PPIs, three cases of nausea and heartburn, and one case of nausea and vomiting. In one other case, the patient was still vomiting, and in four cases, patients were still complaining of bloated stomachs after PPI treatment.

\section{CONCLUSION}

Monitoring and evaluating PPI use should be performed for attaining a proper outcome.

\section{ACKNOWLEDGMENT}

Funding for this study was provide by Universitas Indonesia.

\section{CONFLICT OF INTEREST}

No conflict of interest are declared.

\section{ABBREVIATIONS USED}

PPI: Proton Pump Inhibitor; GSACH: Gatot Soebroto Army Center Hospital; FDA: Food and Drug Administration; GEA: Gastro Enteritis Acute; GERD: Gastro Esophageal Reflux; DM: diabetes Mellitus; CKG: Chronic Kidney Disease; DHF: Dengue Haemorrhagic Fever.

\section{REFERENCES}

1. Katzung BG. (2006). Basic and clinical pharmacology (10th ed.). San Francisco: McGrawHill Lange

2. Lee Yunkyung. (2012). Safety of long term usage of proton pump inhibitors with focus on bone fracture risks. Texas: HEB Pharmacy University of Texas

3. Drug Utilisation Sub-Committee. (2013). Top 10 drugs. Australian Prescriber, 36, 211. https://doi.org/10.18773/austprescr.2013.087.

4. Atkins AM, \& Sekar C. (2013) Proton pump inhibitors: Their misuse, overuse, and abuse. Iosr Journal of Pharmacy, 2013;3(2):25-9. https://doi.org/10.9790/301332202529.

5. Christianti D, Gunadi, RA, \& Ikawati Z. (2014). Evaluasi penggunaan proton pump inhibitor pada pasien rawat inap di rumah sakit baptis Kediri periode desember 2009 - februari 2010. Yogyakarta: Fakultas Farmasi UGM

6. Cipolle RJ, Strand LM, Morley PC. (1998). Pharmaceutical Care Practice.

7. Center for Drug Evaluation and Research FDA. (2010). Proton Pump Inhibitors BPCA Drug Use Review and Duration of Use Analysis. Amerika Serikat: Penulis

8. Muya Y, Murni AW, \& Herman RB. (2015). Karakteristik penderita dispepsia fungsional yang mengalami kekambuhan di bagian ilmu penyakit dalam RSUP Dr. M. Djamil Padang, Sumatera Barat Tahun 2011. Jurnal Kesehatan Andalas 2015;4(2):490-6

9. Nopianto H. (2012). Faktor-Faktor yang Berpengaruh terhadap Lama Rawat Inap pada Pasien Demam Berdarah Dengue di RSUP DR Kariadi Semarang. Semarang: Fakultas Kedokteran Universitas Diponergoro

10. Kasper DL, Braunwald E, Fauci AS. (2009). Harrison's Principle of Internal Medicine (17th ed.).

11. Hughes JD, Tanpurekul W, Keen NC, \& Ee HC. (2009). Reducing the Cost of Proton Pump Inhibitors by Adopting Best Practice. Perth: Radcliffe Publishing

12. American Pharmacists Association. (2009). Drug Information Handbook (17th ed). United States: Lexi-Comp

13. BPOM (Badan Pengawas Obat dan Makanan Republik Indonesia). (2014). Informatorium obat nasional Indonesia. Jakarta: Penulis

14. Ngastiyah. (1997). Perawatan Anak Sakit. Jakarta: EGC

15. Coruzzi G, Adami M, \& Bertaccini G. (1995). Gastric antisecretory activity of lansoprazole in different experimental models: comparison with omeprazole. Gen Pharmac, 26(5):1027-32 https://doi.org/10.1016/0306-3623(94)00278-U. 
16. Lembaga Kebijakan Pengadaan Barang/Jasa Pemerintah (LKPP). (2006). E-katalog obat pemerintah.

17. Krause M. (2002). Food, Nutrition, \& Diet Therapy.

18. Tucker M. (1998). Standar Perawatan Pasien: Proses Keperawatan, Diagnosa, dan Evaluasi (edisi 5). Jakarta: EGC

19. Nelson WE. (2000). Ilmu Kesehatan Anak (edisi 15) (Samik Wahab, Penerjemah). Jakarta: EGC

20. Batuwitage BT, Kingham JGC, Morgan, N. E., Bartlett, R. L. (2007). Inappropriate prescribing of proton pump inhibitors in primary care. Postgrad Med J, 83(975):66-8. https://doi.org/10.1136/pgmj.2006.051151 ; PMid:17267683 PMCid:PMC2599965
21. Lodato F, et al. (2016). Appropriateness of Proton Pump Inhibitor (PPI) prescription in patients admitted to hospital: Attitudes of general practitioners and hospital physicians in Italy. European Journal of Internal Medicine, 30, 31-36. https://doi.org/10.1016/j.ejim.2016.01.025; PMid:26926561.

22. Oktaviani Ira. (2012). Aspek Farmakokinetika Klinik Obat-Obat yang Digunakan pada Pasien Sirosis Hati di Bangsal Interne RSUP DR. M. Djamil Padang Periode Oktober 2011. Januari 2012. Padang: Universitas Andalas

23. Hikmah EN. (2014). Penggunaan Obat-Obatan Penginduksi Penyakit Hati Terhadap Pasien Gangguan Fungsi Hati di Rumah Sakit X Surakarta Tahun 2013. Surakarta: Fakultas Farmasi Universitas Muhammadiyah Surakarta

24. U.S. Department of Veterans Affair. (2005). Criteria for Use of High-dose Ora Proton Pump Inhibitors. Washington DC

Article History: Submission Date:20-01-17; Revision Date: 21-01-17; Accepted Date:18-02-17.

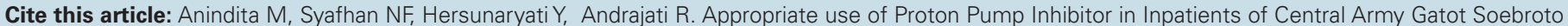
Hospital. J Young Pharm. 2017;9(1)Suppl:s9-s12. 